\title{
TEACHING READING IN VINCENNES, INDIANA
}

\author{
E. O. MAPLE \\ Superintendent of Schools, Vincennes, Indiana
}

In September, r9r6, we changed our purpose and method in teaching reading in all the grades in the Vincennes city schools. The type of recitation formerly used, wherein each pupil was given a chance to stand and read his paragraph "for practice in expression," is no longer seen in our schools. The principles and methods determining the new course in reading are about as follows:

r. Reading is extensive rather than intensive.

2. Pupils read for content rather than for practice.

3. Material is selected for its present value and interest to pupils.

4. Literature requiring adult interpretation and attracting only adult attention is not presented to children.

5. Pupils are not called upon to read orally unless they have something worth reading to a group wanting to hear it. That is, pupils do not read for practice. They read to express thought to those who do not have access to the same material. Supplementary readers are not furnished in sets. Each pupil may have a different book.

6. Pupils need training in listening as well as in expression, and they give better attention to the reading of new material. The reader uses better expression when reading to an attentive audience than to an audience whose faces are thrust in a book, looking for mistakes of the reader.

7. In the recitation an opportunity is given the pupil to read, usually silently, while the teacher observes the speed and later checks up the success in interpretation.

The value of some school experiments is best determined by immediate results. This is true in teaching reading. If the purpose is to encourage rapid and extensive reading and to develop 
a taste for good books, the teacher may measure success by how and what the children read.

In the old course of study there was outlined for the first eight grades 3,270 pages of reading material. On the basis of the rate used in the report of the Cleveland Survey (a pupil should read from 30 to 40 pages per hour) all of the assigned reading could have been done in about roo hours. In the eight years, I, 440 hours were used in the recitations, including time for preparation. That is, in the eight years $\mathrm{I}, 440$ hours were used in reading what should have been read in roo hours. Or the pupils should have read 43,200 pages instead of 3,270 .

Following the schedule of time used, the first grade could have read all assigned to the grade in $2 \frac{1}{2}$ weeks, the second in 8 , the third in $8 \frac{1}{2}$, the fourth in 6 , the fifth in $5 \frac{1}{2}$, the sixth in 4 , the seventh in 5 , and the eighth in $4 \frac{1}{2}$. Or all of the material covered in eight years could have been read in 44 weeks. It is interesting to note that, after the first year, the longer a pupil remained in school the slower he would read.

To correct this difficulty our teachers experimented in various ways and finally agreed upon the plan now in operation. Thus far the results have been better than we expected.

As we began using the present methods in September, r9r6, it will be of interest to compare the report of our school librarian of January, I9r 7, after the method had been in use four months, with the report in January, r9r6. The r9r7 report, when compared with that of r9r6, shows an increase in non-fiction read by pupils of $\mathrm{r}$ ro per cent and of the juvenile fiction of ror per cent.

A questionnaire was sent to all the teachers as follows: "Give the percentage of increase or decrease over that of previous years in time used for oral reading in your grade; in silent reading; in number of pages covered; in amount of reading done outside of school." The teachers were asked to report on the attitude of the pupils toward reading and the reading recitation, and to mention any difficulties and defects observed in the plan.

All but three teachers of the first grade reported an increase in the amount of oral reading of from $\mathrm{I}_{5}$ per cent to $\mathrm{I}_{5} \mathrm{O}$ per cent; all reported an increase of from 15 per cent to roo per cent in the 
amount of silent reading, an increase of 50 per cent to 150 per cent in number of pages covered, and a noticeable increase in the desire to read books outside of school.

All second- and third-grade teachers reported a decrease in the time used in oral reading and an increase of roo per cent to 300 per cent in the time used for silent reading, number of pages covered, and amount of reading outside of school.

These reports all show that in the upper grades much less time is used for oral reading and that there is a marvelous increase in the amount of material read silently and out of school. Teachers report that pupils read everything available and continually add their own contributions to that furnished by the teacher. And in answer to my question, "What are the defects in the plan?" all teachers gave one and only one answer, "Lack of material."

Perhaps the best way to show the attitude of the pupils to the reading work would be to quote from a number of the teachers. Without an exception the opinion of the teachers is expressed as follows: "There is a great deal more interest shown." "The children take my books home and loan their books to other pupils. They want to read books related to their school work." "They love reading." "Pupils ask for new material daily." "This is my first year in Vincennes, but I can see that the interest in reading seems to grow daily, and the amount of good material they are able to cover and to do it well is astonishing." Every teacher states that the pupils show an increased interest in reading and better judgment in selecting material. We are all convinced that much time has been wasted in years past in the reading recitation, and that even better results will be possible in the future. 